\title{
The essential oil yield and compositions of Lemon Verbena (Lippia citriodora Kunth.) cultivated in Ordu ecological conditions*
}

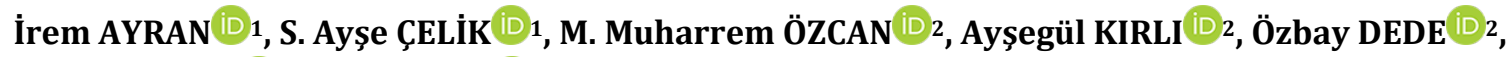 \\ Cevahir ÇiçEK ${ }^{D}$ 1, Yüksel KAN ${ }^{1} 1$
}

1Selçuk University, Agriculture Faculty, Department of Medicinal Plants, Konya, Turkey

20rdu University, Agriculture Faculty, Department of Field Crops, Ordu, Turkey *This article was presented as a poster presentation at 5. International Mediterranean Symposium on Medicinal and Aromatic Plants
(MESMAP5).

Alınış tarihi: 11 Ağustos 2020, Kabul tarihi: 24 Mayıs 2021

Sorumlu yazar: İrem AYRAN, e-posta: irem.ayran@selcuk.edu.tr

\begin{abstract}
Objective: The main objectives of this study are determineted essential oil yield and compositions of lemon verbena, cultivated for the first time, in Black Sea Reagion.
\end{abstract}

\section{Materials and Methods:}

The plant material is obtanied from Atatürk Hortıcultural Central Research Institute, Yalova and cultivated in Ordu. The essential oil components are determined GC-MS system.

Results: Fourteen compounds were identified, representing $85.2 \%$ of the total essential oil. The $59.9 \%$ of total essential oil components are consist of geranial, limonene, neral and 1,8-cineol.

Conclusion: Lemon verbena is suitable and sustainable for agriculture due to the ecological conditions Eastern Black Sea region.

Keywords: Lemon verbena, Lippia citriodora Kunth., geranial, essential oil
Ordu ekolojik koşullarında yetiştirilen Lemon Verbena (Lippia citriodora Kunth.)'nın uçucu yağ verimi ve bileşenleri

\section{$\ddot{0} \mathbf{z}$}

Amaç: Bu çalışmanın amacl, Karadeniz Bölgesi'nde ilk kez yetiştirilen limon otu yapraklarının uçucu yağ verimi ve bileşenlerinin belirlenmesidir.

Materyal ve Yöntem: Bitki materyali Yalova Atatürk Bahçe Kültürleri Merkez Araştırma Enstitüsü'nden temin edilmiştir ve Ordu ilinde yetiştirilmiştir. Uçucu yağ bileşenleri GC-MS sistemi ile belirlenmiştir.

Araştırma Bulguları: Toplam uçucu yağın \%85.2'sini temsil eden on dört bileşik tanımlanmıștır. Toplam uçucu yağ bileșenlerinin \%59.9'u geranial, limonen, neral ve 1,8-sineolden oluşmuştur.

Sonuç: Limon otu Doğu Karadeniz Bölgesi'nin ekolojik koşulları nedeniyle tarıma uygun ve sürdürülebilirdir.

Anahtar Kelimeler: Limon otu, Lippia citriodora Kunth., geranial, uçucu yağ 


\section{Introduction}

Lippia citriodara Kunth. [syn. Lippia triphylla (L'Her.) Kuntze; syn. Aloysia triphylla (L'Her.) Britton], belong to the family Verbenaceae, is commonly known as lemon verbena, tree lemon balm and lemon scented lemon balm. It is named "Limon Otu" in Turkish. Lemon verbena, origin is South America (Argyropouloua,2007), and it is also grown in West India and South Africa (Carnat et al., 1999). Lemon verbena (Lippia citriodora L.), which is not found in the natural flora of Turkey but whose culture has become widespread, is up to 1-3 m height of plant, perennial, deciduous and it has herbs, shrubs and small trees structure. The plant blooms in summer and has numerous small-lilac flowers. The green leaves of lemon balm are long short-petioled, lanceolate (Ceylan, 1987; Gruenwald et al., 2004). In recent years, it has begun to cultivated mild and moderate climate region, in Turkey (Kan,2017).

In Turkey, The cultivation of this plant become widespread economically in the Aegean region and Southeastern Anatolia region. Lemon verbena cultivated in our country are desired in both domestic and foreign markets in terms of yield and quality. As a result, the commercial value of production of this plant is increasing every day, in Turkey.

The aroma and fragrance of the lemon verbena leaves is similar to lemon., and used traditionally as herbal tea, appetizing, flavoring, relaxing the stomach, colds, cough and digestion problems. The parts of lemon verbena used for medical purposes is dried or fresh leaves and branches (Carnat et al.,1999; Gruenwald et al., 2004; Köroğlu et al., 2015;). The infused plant drogs drink 2-3 cups per day due to appetizing, relaxing and diabetes in Turkish folk medicine (Baytop, 1999). The available literature shows that due to the essential oil and phenolic compounds of lemon verbena are used mostly for the treatment of gastrointestinal and respiratory disorders, antimalarial, spasmolitic, antiviral, sedative, hypotensive and, antiinflammatory activities, cytostatic properties (Pascuala et al.,2001), insomnia, anxiety (Carnat et al., 1999; Gruenwald et al., 2004; Setzer, 2009).

The Lemon verbena leaves have essential oil (about 66,3- $69 \%$ of essential oil components consist of geranial, neral and limonene (Argyropouloua,2007)). The plant contain important bio active compounds such as flavonoids (apygenin, diosmetin and luteolin-7-0-glucosides and in addition to mono-, di- and trimethoxyflavones, including eupatorin (Gruenwald et al., 2004), salvigenin, verbascoside, hispidulin, diocirsiliol, chrysoeriol, cismaritin, pectolin- arigenin (Skaltsa and Shammas, 1988; Pascuala et al., 2001) and iridoid (iridoid glycosides including geniposidic acid)( Gruenwald et al., 2004).

According to literature; essential oil of lemon verbana contains citral, geranial, neral, nerol, limonene and linalool (Argyropouloua,2007; Karık and Azkan, 2011; Kan, 2017) and 1,8-cineole, $\alpha$ pinene (Terblanche and Kamelius, 1996; Pascuala et al., 2001; Ebadi et al., 2017).

Essential oils have been used in many fields for different purposes, such as pharmaceutical, food, cosmetic, perfumery, dyeing, aromatherapy and phytotherapy, for many years (Yeşil and Kara, 2012). In addition to usage areas, essential oils have an increasing role in traditional and complementary health practices. According to scientific studies, essential oils of the plants have used antimicrobial, antioxidant, antiinflammatory, carminative, spasmolytic, antiseptic, sedative (Erdoğan, 2012), antifungal, antiviral, antibakteriyal (Faydaoğlu and Sürücüoğlu, 2013, Türkkan et al., 2017), stimulant, antibiotic, antianalgesic, disinfectant, immune system, coloretic, diuretic (Maksimovic et al., 2005).

As a result of the recently increased interest in natural herbal agents, it made important to determine contents of medicinal plants with active compositions such as lemon verbena. The important essential oil obtained from lemon verbena leaves are commonly used phytotherapy and aromatherapy practices. The main objectives of this study are determineted essential oil yield and compositions of lemon verbena, cultivated for the first time, in Black Sea Reagion (Ordu province) with the different ecological conditions.

\section{Materials and Methods}

\section{Plant materials}

In this study, the plant material is obtanied from Republıc Of Turkey Mınıstry Of Agriculture And Forestry, Atatürk Hortıcultural Central Research Institute, Yalova and cultivated in Ordu. Ordu province, is rainly in all months of the year. generally has a mild climate with mild winters and relatively cool summers (Anonymous, 2021a). The soil of the trial area is in clay-loam structure, its $\mathrm{pH}$ is close to neutral, the lime content is low, the amount of organic matter and total nitrogen content is low, the amount of available potassium and phosphorus is 
low. This study was carried out to determine essential oil yield and components of cultivated lemon verbena. The leaves before blooming of this plant was harvested in the second year of plant breeding in May. The harvested leaves were dried at the shade.

\section{Essential oil isolation and Gas chromatography- mass spectrometry (GC-MS)}

The air-dried leaves of lemon verbena were subjected to hydrodistillation for $3 \mathrm{~h}$ using a Clevenger-type apparatus to produce essential oil. The hydrodistillation was done $100 \mathrm{~g} / 500 \mathrm{ml}$ in 3 replications. The obtained essential oil was stored at $-4{ }^{0} \mathrm{C}$ until analysis. Analysis conditions in which essential oil components are determined; The GC-MS analysis was carried out with Agilent 7890 GC-MS system. The relative percentages of the separated compounds were calculated from total ion chromatograms. The identification of the oil components was based on the Wiley and NIST mass spectral library. Chromatographic conditions were “Column; DB-WAX 60 x 0,25 x 0,25, Flow: $1.5 \mathrm{ml} /$ min He, Inlet Temperature: $250{ }^{\circ} \mathrm{C}$, Split Ratio: 40:1, Injection Volume: $1 \mu \mathrm{L}$, MSD Transfer Line Temperature: $250^{\circ} \mathrm{C}$, MS Welding Temperature: 230
${ }^{0} \mathrm{C}$, MS Quadrupol Temperature: $150{ }^{0} \mathrm{C}, \quad$ FID Temperature: $220{ }^{\circ} \mathrm{C}$, FID Dry Air: $400 \mathrm{ml} /$ minute, FID Hydrogen: $30 \mathrm{ml} /$ minute" (EP6, 2007).

\section{Result and Discussion}

The chemical composition of the essential oil of lemon verbena cultivated in Ordu province ecological conditions is summarized in Table 1 . According to the results obtained this study; The essential oil yield of lemon verbena was determined as $1.45 \%$. According to the information given in the Table 1., fourteen compounds were identified, representing $85.2 \%$ of the total essential oil. The main essential oil component of geranial was $20.8 \%$. The other major essential oil components of lemon verbena were determined as limonene (18.1\%), neral (13.8\%), 1,8-cineol (7.2\%), respectively. The $59,9 \%$ of total essential oil components are consist of geranial, limonene, neral and 1,8-cineol. The other detected components of essential oil of lemon verbena were $\alpha$-pinen (1.3\%), sabinene (3.1\%), (E)$\beta$-ocimene (1.6\%), 6-metil-5-hepten-2-on (1.6\%), $\beta$ karyofillen (3.6\%), $\alpha$ - terpineol $(2.1 \%)$, germakren D (3.5\%), $\alpha$-curcumin (4.2\%), karyofillen oksit (1.6\%), spatulenol ( $2.7 \%)$.

Table 1. Essential Oil Components of Lemon Verbena (\%)

\begin{tabular}{cccc}
\hline No & RRI & Compounds & $\%^{*}$ \\
\hline 1 & 1032 & $\alpha$-pinen & 1.3 \\
2 & 1132 & sabinen & 3.1 \\
3 & 1203 & limonene & 18.1 \\
4 & 1213 & 1,8 -cineol & 7.2 \\
5 & 1266 & (E)- $\beta$-osimen & 1.6 \\
6 & 1348 & 6-metil-5-hepten-2-on & 1.6 \\
7 & 1612 & $\beta$ - karyofillen & 3.6 \\
8 & 1694 & neral & 13.8 \\
9 & 1706 & $\alpha$-terpineol & 2.1 \\
10 & 1726 & germakren D & 3.5 \\
11 & 1740 & geranial & 20.8 \\
12 & 1786 & $\alpha$-curcumin & 4.2 \\
13 & 2008 & karyofillen oksit & 1.6 \\
14 & 2144 & spatulenol & 2.7 \\
Total & & & 85.2 \\
\hline
\end{tabular}


In the researches, the essential oil yields of lemon verbena varied from $0.16 \%$ to $1.93 \%$ in Southern Serbia (Elechosa et al., 2017). The conducted other studies, for different harvest time, lemon verbena (Lippia citriodora L.) the average essential oil yields were determineted between $0.88 \%$ and $0.92 \%$ in Yalova ecological conditions ( Karlk and Azkan, 2011) and the essential oil yield of lemon verbena was determined 0,2\% (Terblanche and Kamelius, 1996) and subjected to yield dried leaf 1,2\% (Özek et al., 1996), essential oil yield of dried leaves of lemon verbena were varied from $0.81 \%$ to $1.19 \%$ (Rode, 2000). According to different phenological stages, essential oil yield of $L$. citriodora determined as $0,25 \%$ (fruit set), 0,48\% (vegetative) and 90\% (full flowering) (Reza et al., 2013) and Karlk et al. (2019) reported that according to diurnal variability, the essential oil yields of lemon verbena leaves was detected $0.78 \%$ and $1.64 \%$. In this study, the essential oil yield of lemon verbena was determined as average $1.45 \%$ in Ordu ecological conditions. Essential oil yield obtained from our study was determined different from other studies datas. Essential oil yield may be effect from differences such as geographical location, cultivation conditions, climatic conditions, harvest time, drying and storage conditions of plants.

According to a study; The main constituents were geranial, neral and limonene constituting $69 \%$ of the total essential oil of lemon verbena harvested in May and increasing to $66.3 \%$ in September. In May (the vegetative stage), the analysis of the main components found geranial (38.7\%), neral (24.5\%) and limonene (5.8\%) and In September (flowering period), the analysis of the main components found, geranial (26.8\%), neral (21.8\%) and limonene (17.7\%) (Argyropouloua et al., 2007). The other study, the main essential oil constituents of Lippia citriodora were citral-a $(37,10 \%)$, citral-b $(22,34 \%)$, 1,8 -cineole $(15,93 \%)$, geranial $(10,60 \%)$ and the others were linalool $(1,01 \%)$, limonene $(0,91 \%)$, alfapinene (0,52\%), respectively (Terblanche and Kamelis, 1996). In the study of Karlk and Azkan (2011), according to harvest time, the main essential components of the 1st harvest in 2017 were limonene (33.7\%), geranial (17.6\%) and neral (12.3\%), while the main essential components of the 2st harvest in 2017 were geranial (\%32.4), neral(\%18.1) and limonene(\%17.8). When the main essential components of the 1st and 2st harvest in 2018 were examined, the main essential components of 1st harvest were limonene (5.2\%), geranial $(6.2 \%)$, neral $(12.5 \%)$ and 2 st harvest were geranial (33.6\%), neral (19.7\%), limonene (16.3\%). According to datas obtained from in our study, the main essential oil components of geranial was 20.8 $\%$, limonene was $18.1 \%$, neral was $13.8 \%$ and 1,8cineol was $7.2 \%$. This components are consist of 59.9 $\%$ of the total components. The reasons for the resulting differences of essential oil components can be harvest time, development stage of plant, growing conditions, climatic conditions and drying and storage conditions of the plant.

According to our results, Lemon verbena cultivated in Ordu in order to both the yield of essential oil and the amount of the important essential oil contents. Many factors such as geographical distribution, climatic conditions, drying methods, distillation method and time, harvest time and period, applied plant growth regulators affect the essential oil yield and components(Sefidkon et al., 2006; Kara and Baydar, 2013; Yildirim et al. 2019). The differences of essential oil yield and components may vary according to geographical location, harvest time, drying and storage conditions, variety of ecological and climatic factors, soil structure, total temperature, growing conditions. distillation method and time, harvest time and period.

\section{Conclusion}

As results of this study were determineted to be important essential oil yield and compositions of lemon verbena leaves and in the Eastern Black Sea Region, the cultivation of this plant, valuable in terms of essential oil, will provide an important source of herbal raw materials. When this study compared to the literature, this study has been found to give parallel results both in terms of essential oil yield and compositions. It can be said that lemon verbena is suitable and sustainable for agriculture due to the ecological conditions Eastern Black Sea region.

\section{Conflicts of Interest}

The authors declare no conflicts of interest.

\section{Authorship contribution statement}

ÖD, MMÖ, AK: Contributed to the procurement of materials required for the research, the establishment and execution of the trials.

İA, SAÇ, CÇ, YK: They contributed to the stages of analysis, obtaining and evaluating data, and the datas converted the results into articles. 


\section{References}

Anonymous, 2021a. Ordu Provincial Directorate of Culture and Tourism, Geography. https://ordu.ktb.gov.tr/. (Date of access: 29.04.2021)

Argyropouloua, C., Daferera, D., Tarantilis, P. A., Fasseasa, C. \& Polissio, M. (2007). Chemical Composition of The Essential Oil From Leaves of Lippia citriodora H.B.K. (Verbenaceae) At Two Developmental Stages. Biochemical Systematics and Ecology, 35(12), 831-837.

Baytop, T. (1999). Türkiye'de Bitkiler ile Tedavi, Nobel Tıp Kitabevleri, ISBN:975-420-021-1,287.

Carnat, A., Carnat, A.P., Fraisse, D. \& Lamaison, J.L. (1999). The Aromatic And Polyphenolic Composition of Lemon Verbena Tea, Fitoterapia, (70), 44-49.

Ceylan, A. (1987). Tıbbi Bitkiler II. Uçucu Yağ İçerenler. Ege Üniversitesi Ofset Basımevi, Bornova, İzmir, 175179.

Ebadi, M. T., Azizi, M.,Sefidkon, F. \& Ahmadi, N. (2015). Influence of Different Drying Methods on Drying Period, Essential Oil Content and Composition of Lippia citriodora Kunth.Journal of Applied Research on Medicinal and Aromatic Plants, (2),182-187.

Ebadi, M.T., Sefidkon, F., Azizi, M. \& Ahmadi, N. (2017). Packaging Methods and Storage Duration Affect Essential Oil Content and Composition of Lemon Verbena (Lippia citriodora Kunth.). Food Sci Nutr., (5):588-595. https://doi.org/10.1002/fsn3.434.

Elechosa, M.A., Lira, P.D.L., Juarez, M. A., Viturro, C.I., Heit, C. I., Molina, A. C., Martinez, A. J., Lopez, S., Molina, A. M., Baren, C. M. \& Bandoni, A. L. (2017). Essential Oil Chemotypes of Aloysia citriodora (Verbenaceae) in Northwestern Argentina, Biochemical Systematics and Ecology, (74):19-29.

Erdoğan, E.A. (2012). Bitki Uçucu Yağlarının Kullanım Alanları ve Muhtemel Genetik Etkileri. Lokman Hekim Journal, 2(2),21-24.

EP6, 2007, European Pharmacopoeia Sixth Edition, Council of Europe, Strasbourg: France.

Faydaoğlu, E. \& Sürücüoğlu, M.S. (2013). Tıbbi ve Aromatik Bitkilerin Antimikrobiyal, Antioksidan Aktiviteleri ve Kullanım. EÜFBED - Fen Bilimleri Enstitüsü Dergisi, 6(2),233-265.

Gruenwald, J., Brendler, T. \& Jaenicke, C. (2004). PDR for Herbal Medicines Londra, Thomson Healthcare, ISBN: 1-56363-361-2, 1-858.
Kara N, Baydar H (2013) Determination of lavender and lavandın cultivars (Lavandula sp.) containing high quality essential oil in Isparta, Turkey. Turk J Field Crops, 18(1): 58-65.

Kan, Y. (2017). Doğu Karadeniz Bölgesi Tıbbi Ve Aromatik Bitkilerin Envanterinin Çıkarılmasl, Ticari Kullanımının Araștırılması Ve Üreticilerin Eğitimi Projesi Eğitim Kitabı. DOKAP. 1-178.

Karık, Ü. \& Azkan, N. (2011). Farklı Dikim Aralıklarının Limonotu (Lippia citriodora L.) Bitkisinde Herba ve Uçucu Yağ Verimi ile Uçucu Yağın Kalite Özelliklerine Etkisi, $B A H C ̧ E, 40$ (1), 23 - 34.

Karık, Ü., Çınar, O., Tunçtürk, M. \& Şekeroğlu, N. (2019). Morphological And Dilurnal Variability Of Essential Oil in Lemon Verbena (Lippia citriodora H.B.K.). Anadolu, J. of AARI, 29 (2),114-120. E-ISSN: 2667-6087.

Köroğlu, A., Altanlar, N., Kendir, G. \& Şimşek, D. (2015). Piyasadaki Aloysia citriodora Palau Örneklerinde Antioksidan Kapasite ve Mikrobiyolojik Kontaminasyon, Türk Mikrobiyol Cem. Dergisi, 45(3),136-144, doi:10.5222/TMCD.2015.136.

Maksimovic, Z.A., Dordevic, S. \& Mraovic, M. (2005). Antimicrobial Activity of Chenopodium botrys Essential Oil. Fitoterapia, (76),112-114.

Özek, T., Kirimer, N., Baser, K. \& Tümen, G. (1996). Composition of The Essential Oil of Aloysia triphylla (L'Herit.) Britton Grown in Turkey. Journal of Essential Oil Research, (8),581-583.

Pascuala, M.E., Slowinga, K., Carreteroa E., SánchezMata, D. \& Villara, A. (2001). Lippia: Traditional Uses, Chemistry and Pharmacology: A Review. Journal of Ethnopharmacology, 76(3),201-214.

Rode J. (2000). Possibilities of Lippia citriodora Kunth. Cultivation in Slovenia. Acta Hort., 523,61-64.

Sefidkon F, Abbasi K, Khaniki GB (2006) Influence of Drying and Extraction Methods on Yield and Chemical Composition of the Essential Oil of Satureja hortensis. Food Chem. 99: 19-23.

Setzer, W.N. (2009). Essential Oils and Anxiolytic Aromatherapy. Natural Product Communications, $4(9), 1305-1316$.

Shahhoseini, R., Beyraghdar, A., Karimi, S.R. \& Ebadi, M.T. (2013). Essential Oil Content and Composition of Lemon Verbena (Lippia citriodora Kunth.) During Different Phenological Stages. Journal of Medicinal Plants and By-products, 2,205-208. 
Skaltsa, H. \& Shammas, G. (1988). Flavonoids From Lippia citriodora. Planta Medica, 54, 465.

Terblanche, F.C. \& Kornelius, G. (1996). Essential Oil Constituents of The Genus Lippia (Verbenaceae)-A Literature Review. Journal of Essential Oil Research (8),471-485.

Türkkan, M., Çalışkan, Ö., Erper, İ., Kara, Ş. M., \& Açıkgöz, M. A. (2017). Bazı toprak kökenli funguslara karşı defne esansiyel yağı ve hidrosölünün antifungal etkilerinin belirlenmesi. Akademik Ziraat Dergisi, $8(2), 217-226$.
Yeşil, M., \& Kara, K. (2012). Mentha spicata L. ve Mentha villoso-nervata L. genotiplerinin bazı uçucu yağ bileșenleri üzerine farklı azot ve fosfor dozlarının etkisi. Akademik Ziraat Dergisi, 6(2), 131-140.

Yıldırım MU, Sarıhan EO, Kul H, Khawar KM (2019) Diurnal and nocturnal variability of essential oil content and components of Lavandula angustifolia Mill. (Lavender). MKU. Tar. Bil. Derg. 24(3):268-278. 